\title{
THE EFFECT OF INFLATION, POVERTY, AND INVESTMENT ON SUSTAINABLE DEVELOPMENT IN WEST KALIMANTANPROVINCE
}

\author{
Sukma Febrianti $^{1 *}$, Junita Indriyati ${ }^{2}$ \\ ${ }^{1,2}$ Study Programme of Management \\ STIE Pontianak, West Kalimantan, Indonesia \\ *Corresponding author:sukma_febri@yahoo.co.id
}

\begin{abstract}
The purpose of this study is to examine how big the effect of Inflation, Poverty, and Investment have on Sustainable Development in West Kalimantan Province, partially or simultaneously. Sustainable Development in this study was measured using the Human Development Index (HDI) indicator. This research was conducted because the development of West Kalimantan HDI, when compared to other provinces in Kalimantan, still occupies the lowest position. This research was a quantitative descriptive and used secondary data, the West Kalimantan Financial Report and inflation data. The data used in this study was the annual time series data from 2007-2016. The analysis technique used in this study was Multiple Linear Regression by using SPSS version 25. The partial test results showed that Inflation and Investment had no effect on Sustainable Development in West Kalimantan Province, while Poverty had an effect on Sustainable Development in West Kalimantan Province. Based on the results of the F Test, it showed that Inflation, Poverty and Investment simultaneously had effects on Sustainable Development in the province of West Kalimantan.
\end{abstract}

Keywords: Inflation, Poverty, Investment, Sustainable Development

Received December $^{16 \text { th }} 2019 \quad$ Revision January ${ }^{8 \text { th }} 2020 \quad$ Accepted for Publication January ${ }^{17 \text { th }} 2020$

\section{INTRODUCTION}

Sustainable Development Goals (SDGs) are proposed to be a development of sustainability and equality that is able to face new challenges that will benefit future generations. Sustainable Development not only concentrates on environmental issues but is broader than that which includes economic development and social development.

Fauzi (2009) explains that the concept of sustainability is a simple, yet complex concept hence the notion of sustainability is very multidimensional and multi-interpreted. The concept of SDGs has 17 goals including a number of targets related to human development, namely the third, fourth and eighth goals. The third goal is to guarantee a healthy life and improve the welfare of the population at all ages. The fourth goal is to guarantee the quality of education that is fair and inclusive and increase the opportunity for life-long learning for all, while the eighth goal is to promote inclusive and sustainable economic growth, full and productive employment opportunities, and decent work for all (Human Development Index, 2: 2017). 
Based on the Human Development Report (HDR) in 2016, the United Nations Development Program (UNDP) noted that HDI in Indonesia is still in the status of "medium" human development and is still lagging behind countries in ASEAN, such as Singapore, Malaysia, Brunei Darussalam and Thailand, which means that development in Indonesia has not been evenly distributed, therefore the role of local governments in realizing sustainable development is needed. UNDP reported that Indonesia's HDI in 2015 reached 0.689, but there are still imbalances in human development in Indonesia. Indonesia's HDI that has been corrected with inequality (IHDI) only reached 0.563 . The amount of inequality which is shown by a decrease to 18.2 percent. The potential for human development that could have been achieved was not optimal because of the decline. The development of West Kalimantan's HDI, when compared to other provinces in Kalimantan, still occupies the lowest position.

The development of HDI in Indonesia and West Kalimantan in 2007-2016 are as follows:

Table 1

The development of HDI in Indonesia and West Kalimantan in 2007-2016

\begin{tabular}{ccccc}
\hline Year & Indonesia & West Kalimantan & Development & Rank \\
\hline 2007 & 70,59 & 67,53 & 0,45 & 29 \\
2008 & 71,17 & 68,17 & 0,64 & 29 \\
2009 & 71,76 & 68,79 & 0,62 & 28 \\
2010 & 72,27 & 69,15 & 0,36 & 28 \\
2011 & 72,77 & 69,66 & 0,51 & 28 \\
2012 & 73,29 & 70,31 & 0,65 & 28 \\
2013 & 73,82 & 70,93 & 0,62 & 29 \\
2014 & 68,90 & 64,89 & $-6,04$ & 30 \\
2015 & 69,55 & 65,59 & 0,70 & 29 \\
2016 & 70,18 & 65,88 & 0,29 & 29 \\
\hline
\end{tabular}

Source: Central Statistics Agency

The HDI of West Kalimantan from 2007-2016 shows that the province's HDI has increased. Although the increase is below $0.5 \%$ per year, the trend continues to improve. HDI in West Kalimantan Province is still in the status of "medium" and based on the obtained data, West Kalimantan is in a ranking of 10 provinces with the lowest HDI.

Many factors can affect sustainable development, for example, inflation, poverty and investment. Based on previous studies, research on Sustainable Development is still rarely conducted, but the HDI indicators have been included in many previous studies but with different variables and there are still differences in research results so researchers 
want to reexamine the research with different samples. Manik's research (2013) shows that the Inflation variable does not affect the HDI, while poverty affects the HDI.Zainudin (2015) and Rohmah (2017) research shows that there is an effect of inflation on the Human Development Index. Fatimah's research (2018) states that poverty has no significant effect on HDI while Dewi (2017) states that poverty has a significant effect on HDI. Royan's research (2015) states that investment affects the Human Development Index.

\section{LITERATURE REVIEW}

According to Madura (2007), inflation is an increase on the level of prices of goods $\&$ services in general over a certain period of time. The inflation rate can be estimated by measuring the percentage change in the consumer price index, which indicates the price of a large number of consumer products. Factors that can cause an inflation include costs and demand, a situation where higher prices are imposed by companies as a result of higher production costs due to high demand or in this case it is called demand pull inflation. A situationin which prices of products and services are pulled up due to strong consumer demand.

Jeff Madura also explained that inflation consists of 4 types, such as:

- Creeping inflation is an inflation that is easy to control and has not disrupted a country's economy. An increase in prices of goods / services in general, which is under $10 \%$ per year and can be controlled.

- Walking inflation is an inflation that can reduce the level of prosperity of the middleincome people, but it does not endanger the economic activities of a country. This inflation is in the range of $10 \%-30 \%$ per year.

- Galloping inflation is an inflation which results in economic chaos in a country. In this condition, people generally prefer to save goods instead of money because the interest is much lower than the value of inflation. This inflation is in the range of $30 \%-100 \%$ per year.

- Hyperinflationis an inflation that has messed up a country's economy and is very difficult to control despite monetary and fiscal policies. This inflation is in the range of $100 \%$ and above per year.

According to Husnan (2017), investment is a delay of current consumption to be put into productive assets for a certain period of time. Investment in earning assets can be in the form of real assets (houses, land and gold) or in the form of financial assets (securities) that are traded among investors. Investors make investments to improve their utility in the form of financial welfare. Investments in financial assets can be in the form of direct investments and indirect investments. Direct investment can be done by buying financial assets that can be traded on the money market or capital market while indirect investment is done by buying securities from investment companies. 
According to the Central Statistics Agency (BPS),HDI explains how residents can access the results of development in obtaining income, health, education, and so on. HDI was introduced by the United Nations Development Program (UNDP) in 1990 and is published regularly in the annual Human Development Report (HDR) report.

HDI is formed by 3 (three) basic dimensions:

1) Long life and healthy life

2) Knowledge

3) A decent standard of living

Benefits of HDI include important indicators to measure success in efforts to build the quality of life of people (community / population), HDI can determine the rank or level of development of a region / country, for Indonesia, HDI is a strategic data because in addition to being a measure of Government performance, HDI is also used as one of the allocators to determining the General Allocation Fund (DAU).

\section{$\mathrm{H}_{1}$ : There is anEffect of Poverty, Inflation and Investment on Sustainable Development in the West Kalimantan Province.}

\section{RESEARCH METHODS}

\section{Hypothesis Testing and Analysis Techniques}

\section{Classical Assumption Test}

a. Normality test

Normality Test is used to test whether in a regression, confounding, or residual variables have a normal distribution. The analytical model used for testing is the Shapiro-Wilk Test.

b. Multicollinearity Test

According to Imam Ghozali (2011: 105), multicollinearity test aims to test whether the regression model find a correlation between independent variables (independent). It is said that multicollinearity occurs if the tolerance value is less than 0.10 or the VIF value is greater than 10 .

c. Heteroscedasticity Test

A good regression model is a regression model that has homoscedasticity data or there is no heteroscedasticity occurred.

d. Autocorrelation Test

A good regression model is a regression that is free from autocorrelation so it can be more efficient. To detect the presence or absence of autocorrelation problems is conducted through testing the Durbin-Watson value (DW Test).

\section{Multiple Linear Regression Analysis}


This study used Multiple Linear Regression to see the effect of independent variables on the dependent variable with SPSS version 25.

a. Partial Test ( $\mathrm{t}$ Test)

This test is conducted to test the significance of independent variables on the dependent variable individually, this is done by comparing $t$ count with $t$ table at the level of significant $5 \%$ with the following decision-making criteria:

- If $\operatorname{sig}()$ statistics $<5 \%$, then $\mathrm{H}_{1}, \mathrm{H}_{2}$, and $\mathrm{H}_{3}$ are accepted

- If sig () statistics $>5 \%$, then $\mathrm{H}_{1}, \mathrm{H}_{2}$, and $\mathrm{H}_{3}$ are rejected

b. Simultaneous Significance Test (F Test)

$\mathrm{F}$ test is performed to test the significance of the independent variables on the dependent variable. Testing is carried out by comparing the $\mathrm{F}$ count with the $\mathrm{F}$ table at the level of significant $5 \%$ with the following decision-making criteria:

- If sig () statistics $<5 \%$, then $\mathrm{H}_{4}$ is accepted

- If sig () statistics $>5 \%$, then $\mathrm{H}_{4}$ is rejected

c. Coefficient of Determination

The coefficient of determination test is carried out to find out the level of accuracy in regression analysis, this is indicated by the magnitude of the coefficient of determination ( $\mathrm{R}^{2}$ adjusted) between zero and one or $0<\mathrm{R}^{2}<1$.

\section{RESULT AND DISCUSSION}

\section{Classical Assumption Test}

To conduct test using multiple linear regression it is required to conduct the Classical Assumption Test first and the result of this test is presented in a table below:

a. Normality Result

Table 2

Test of Normality Result

\begin{tabular}{|c|c|c|c|c|c|c|}
\hline & \multicolumn{3}{|c|}{ Kolmogorov-Smirnov } & \multicolumn{2}{|c|}{ Shapiro-Wilk } & \multirow[b]{2}{*}{ Sig. } \\
\hline & Statistic & $\overline{d f}$ & Sig. & Statistic & $\overline{\mathrm{df}}$ & \\
\hline \multicolumn{7}{|c|}{ Unstandardized } \\
\hline Residual &, 227 & 10 & 156 & ,926 & 10 & ,409 \\
\hline
\end{tabular}

a. Lilliefors Significance Correction

Source: Processed Data by SPSS version 25, 2019 
Based on the table above, it can be seen that the Shapiro-Wilk sig value of 0.409 is higher than 0.05 , which means that the data has normal distribution, which implies that it is eligible for multiple linear regression testing.

b. Multicollinearity Test

Table 3

Multicollinearity Test Result

Coefficients $^{\mathbf{a}}$

Collinearity Statistics

\begin{tabular}{clrr}
\hline Model & & Tolerance & VIF \\
1 & (Constant) &, 855 & \\
& Inflasi &, 382 & 1,169 \\
& Kemiskinan &, 353 & 2,615 \\
& Investasi & 2,834 \\
\hline
\end{tabular}

a. Dependent Variable: Sustainable Development

Source: Processed Data by SPSS version 25, 2019

Based on the table above, the result of the Tolerance value test show that there are no independent variables (Inflation, Poverty and Investment) that have a value of less than 0.10 , which means there is no correlation among independent variables. VIF test result are less than 10, so it can be concluded that there is no multicollinearity between variables in this model so that multiple linear regression testing can be carried out.

c. Heteroscedasticity Test

Table 4

Heteroscedasticity Test Result

\begin{tabular}{llcc}
\hline & & Coefficients $^{\mathbf{a}}$ & \\
& & Model & Sig \\
\hline 1 & (Constant) &, 319 &, 761 \\
& Inflasi & 1,127 &, 303 \\
& Kemiskinan &,- 812 &, 448 \\
& Investasi & 1,514 &, 181 \\
\hline
\end{tabular}

a. Dependent Variable: Sustainable Development

Source: Processed Data by SPSS version 25, 2019

Based on the table above, it shows that the significant value of each variable (inflation, poverty and investment) is more than 0.05 which means that the regression 
model in this study has no heteroscedasticity so that multiple linear regression testing can be carried out.

d. Autocorrelation Test

\section{Table 5}

Autocorrelation Test Result

\begin{tabular}{cccccc}
\hline & & & \multicolumn{4}{c}{ Model Summary } \\
Model & $\mathbf{R}$ & R Square & Adjusted & Std. Error of & \\
& & & RSquare & theEstimate & \\
\hline 1 &, $670^{\mathrm{a}}$ &, 448 &, 173 & 1,88768 & 2,534 \\
\hline
\end{tabular}

a. Predictors: (Constant), inflation, poverty and investment

b. Dependent Variable: Sustainable Development

Source: Processed Data by SPSS version 25, 2019

Based on the table, it shows that the DW value of 2.534. This value will be compared with the Durbin Watson table with a significance value of 5\%. The amount of data in this study is 10 and the independent variable was $3(\mathrm{k}=3)$, from the DW table, the value of $d_{u}$ is 2.0163 . So, it can be stated that there is no autocorrelation problem in the regression model in this study, because the DW value is higher than the value of $D_{u}$ which is $2.534>2.0163$, so it already meets the requirements to be tested with multiple linear regression.

\section{Multiple Linear Regression Analysis}

Multiple Linear Regression Analysis was done by processing data using SPSS version 25 which is formulated as follows:

$$
\mathrm{Y}=2,179-0,219 \times 1-0,018 \times 2+0,005 \times 3+e
$$

Note:

$\mathrm{Y} \quad=$ Sustainable Development

$\mathrm{X} 1=$ Inflation

$\mathrm{X} 2=$ Poverty

$\mathrm{X} 3=$ Investment

From the equation above,it can be concluded that:

- If Inflation, Poverty and Investment in West Kalimantan Province are 0 or none, then Sustainable Development is at a constant value of 2.179 .

- If Poverty and Investment value is fixed and Inflation is increased by 1 unit, then Sustainable Development will decrease by 0.219 . 
- If the inflation and investment value is fixed and poverty is increased by 1 unit, then Sustainable Development will decrease by 0.018 .

- If the inflation and poverty value are fixed and investment is increased by 1 unit, then Sustainable Development will increase by 0.005 .

a. Partial Test (t Test)

Table 6

t-Test Result

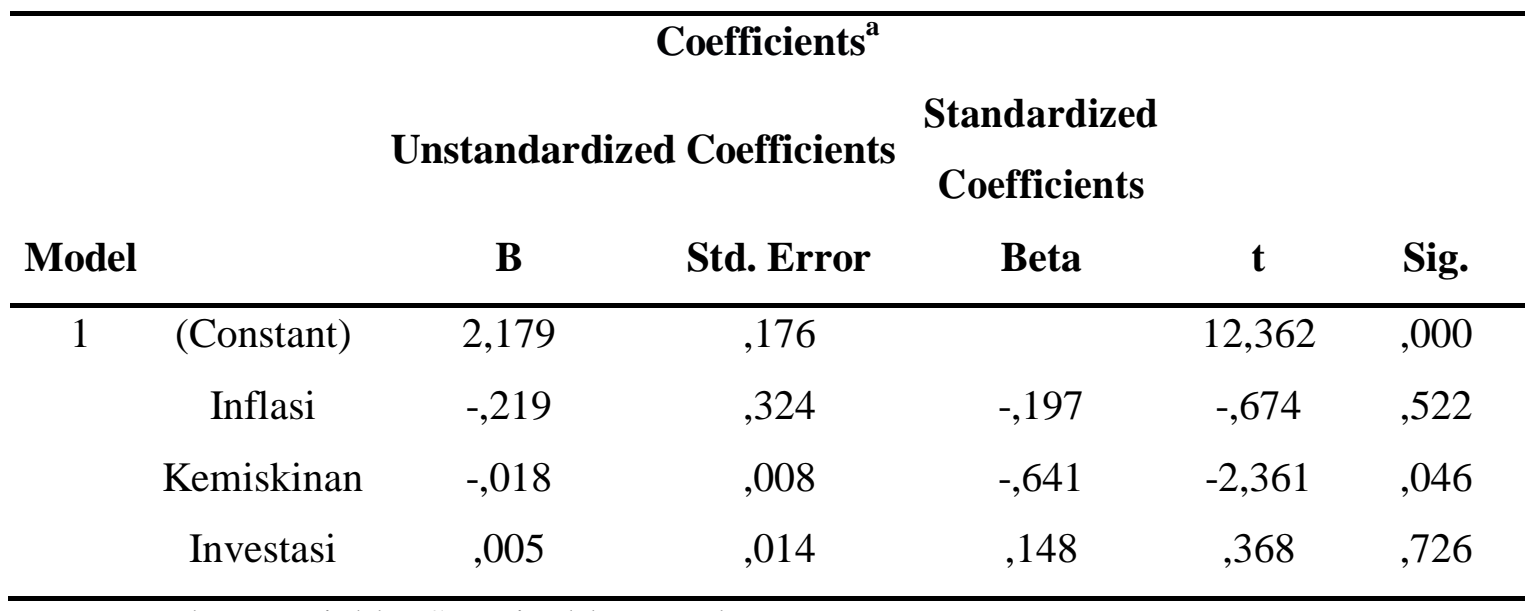

a. Dependent Variable: Sustainable Development

Source: Processed Data by SPSS version 25, 2019

Based on the table above, it can be seen that inflation and investment have $\mathrm{t}_{\text {value }}<\mathrm{t}$ table, while poverty has a $\mathrm{t}$ value $>\mathrm{t}$ table. The $\mathrm{t}$ table value is 1.895 . Therefore, it can be concluded that:

- Inflation shows the probability of sig. of $0.522>0.05$ while the value of $t$ count of -0.674 $>-1.895$, so it is concluded that inflation has no significant effect on Sustainable Development in West Kalimantan Province. These result supports research conducted by Indah Pangesti and Rudy Susanto that inflation has a negative and insignificant effect on the Human Development Index (HDI).

- Poverty shows the probability of sig. is $0.046<0.05$, while the $t$ value was $-2.3361<-$ 1.895. So it was concluded that poverty has a significant and negative effect on Sustainable Development in West Kalimantan Province. This result is in line with research conducted by DenniSulistioMirza that Poverty has a negative and significant effect on the Human Development Index (HDI).

- Investment shows the probability of sig. is $0.726>0.05$, while the $t$ value was 0.368 <1.895. So it was concluded that investment had significant effect on Sustainable Development in West Kalimantan Province. These result is similar to research 
conducted by HendriPanggayuh which states that investment has significant effect on HDI.

From the results of the partial analysis above, it appears that investment has an important role in the growth of Sustainable Development or the Human Development Index because out of the three independent variables, only investment has a significant and positive effect, which means that: when the investment climate in West Kalimantan increases, it will have an impact on improving the Sustainable Development index.

b. Simultaneous Significance Test (F Test)

Table 7

F Test Result

\begin{tabular}{|c|c|c|c|c|c|c|}
\hline & \multicolumn{6}{|c|}{ ANOVA $^{a}$} \\
\hline & Model & Sum of Squares & df & Mean Square & $\mathbf{F}$ & Sig. \\
\hline \multirow[t]{3}{*}{1} & Regression & ,004 & 1 & ,004 & 5,985 &, $040^{b}$ \\
\hline & Residual &, 005 & 8 & ,001 & & \\
\hline & Total & .008 & 9 & & & \\
\hline
\end{tabular}

a. Predictors: (Constant), inflation, poverty and investment

b. Dependent Variable: Sustainable Development

Source: Processed Data by SPSS version 25, 2019

Anova result shows that the $F_{\text {count }}$ is 5.985 with sig 0.040 , while the $F_{\text {table }}$ is 4.760 . It can be seen that $F_{\text {count }}>F_{\text {table }}$ with a value of $5.985>4.760$ with a significant value of $0.040<0.05$ which means that inflation, poverty and investment have a significant effect towards Sustainable Development.

c. Coefficient of Determination

Table 8

Coefficient of Determination $\left(\mathbf{R}^{2}\right)$

\section{Model Summary}

Model R R Square Adjusted R Square Std. Error of the Estimate

\begin{tabular}{ccccc}
\hline 1 &, $689^{\mathrm{a}}$ &, 475 &, 01180
\end{tabular}

a. Predictors: (Constant), inflation, poverty and investment

Source: Processed Data by SPSS version 25, 2019 
Based on the table above, it shows that the Adjusted $\mathrm{R}^{2}$ value is 0.475 or $47.5 \%$ which means that the independent variable, Sustainable Development, is only able to explain the dependent variable, Inflation, Poverty and Investment, around $47.5 \%$ while the remaining $53.5 \%$ is influenced by other variables which were not analysis in this study.

\section{CONCLUSSIONS}

Based on the results of research that has been done, then the conclusion in this study are Partially, Inflation and poverty have insignificant effect on Sustainable Development in West Kalimantan Province while investment has a significant and positive effect on Sustainable Development.Inflation, Poverty and Investment simultaneously have a significant effect on Sustainable Development in West Kalimantan Province.The effect of Inflation, Poverty, and Investment is $47.5 \%$ on Sustainable Development, while the remaining $52.5 \%$ is by other variables which are not included in this study.Investment variable is the only variable that has a significant effect on Sustinable Development in West Kalimantan Province. Investment has a positive effect which means that when the investment climate improves it will have an impact on increasing HDI in West Kalimantan Province.

\section{REFERENCES}

BadanPusatStatistik. 2016. Kalimantan Barat DalamAngka 2016.Juli.BPS Provinsi Kalimantan Barat.

BadanPusatStatistik. 2017. Indeks Pembangunan Manusia.Agustus.BPS Provinsi Kalimantan Barat.

Dewi, Novita. 2017. PengaruhKemiskinandanPertumbuhanEkonomiterhadapIndeks Pembangunan Manusia di Provinsi Riau.JOM Fekon 4(1): 880-881.

Fatimah, NurSiti. 2018. AnalisisPengaruhKemiskinan, Pengangguran, PertumbuhanEkonomiTerhadapIndeks Pembangunan Manusia di ProvinsiBantenTahun 2010-2015. Skripsi.Universitas Islam Indonesia.

Fauzi, Akhmaddan Alex Oxtavinus. 2014. The Measurement Of Sustainable Development in Indonesia. JurnalEkonomi Pembangunan 15(1) : 68-83.

Hartono, Jogiyanto. 2017. Teori Portofolio dan Analisis Investasi. Edisi Kesebelas. BPFE Yogyakarta.

Imam, Ghozali. 2011. AplikasiAnalisis Multivariate dengan Program IBMSPSS 19. Edisi 5.Semarang: BadanPenerbitUniversitasDiponegoro.

Manik, Tumpal. 2013. AnalisaPengaruhKemakmuran, UkuranPemerintah Daerah, Inflasi, Intergovernmental 
RevenuedanKemiskinanterhadappembangunanmanusiadanPertumbuhanEkonomi. JurnalOrganisasidanManjemen 9(2) : 123

Maskartini.Tribun Pontianak. 2017. RealisasiInvestasi se-Kalimantan, KalbarPeringkatKeduaSetelahKaltim.31 Mei.Kalimantan Barat.http://pontianak.tribunnews.com/2017/05/31/realisasi-investasi-kalbar-sekalimantan-kedua-setelah-kaltim .Senin, 21 Januari 2019 12:44

Mirza, DenniSulistio. 2011.PengaruhKemiskinan, PertumbuhanEkonomi, danBelanja Modal Terhadap IPM Jawa Tengah. JEJAK, 4(2).

Panggayuh, Hendri. 2016. Pengaruh Belanja Negara dan Investasi terhadap Pembangunan Ekonomi Kabupaten/Kota di Provinsi Jawa Tengah. Jurnal Eko Regional 11(1) : 27-35.

Pangesti, Indah dan Rudy Susanto. 2018. Pengaruh Inflasi terhadap Indeks Pembangunan Manusia (IPM) di Indonesia. Journal of Applied Business and Economics 5(1) : 7081.

Pontianak Post. 2018. Pembangunan KalbarTidakMerata. 19 September, Kalimantan Barat.https://www.pontianakpost.co.id/pembangunan-kalbar-tidak-merata.Kamis, 20 Desember $2018(10: 45)$

Rohmah, $\quad$ RinaNur. 2017.AnalisisFaktor-faktor yang mempengaruhiindekspembangunanmanusia di provinsijawatengahtahun 20122014.

JurnalekonomipembangunanFakultasEkonomidanBisnisUniversitasMuhammadiyah Surakarta.

Royan, Miftahur. AisahJumiatidanFajarWahyu Prianto.2015.PengaruhInvestasiPublikdanSwastaterhadappeningkatanIndeks Pembangunan Manusia di JawaTimur.ArtikelIlmiahMahasiswa.

Sunariyah. 2003. PengantarPengetahuanPasar Modal, edisiketiga. UPP-AMP YKPN, Yogyakarta.

Todaro, Michael P dan Stephen C. Smith.2011.Pembangunan Ekonomi, EdisiKesebelas, Jilid 1. Jakarta: PenerbitErlangga.

United Nations Development Programme (UNDP). 2016. Human DepelopmentReport (HDR) 2016. UNDP. Washington DC, USA.

Zainuddin. 2015. AnalisisDampakInflasi, PDRB danPerkembanganUpah Minimum Regional TerhadapIndeks Pembangunan ManusiaMasyarakat di Provinsi Aceh. JurnalEkonomiManajemendanAkuntansi 1(1) : 45-5 